\title{
Lekka kompozytowa struktura nośna - koncepcja, wstępne badania, możliwości rozwoju
}

\author{
Composite space structure - idea, tests and development
}

\section{DANIEL DECBSKI KRZYSZTOF GOŁOŚ*}

DOI: 10.17814/mechanik.2016.12.577

\begin{abstract}
Artykuł przedstawia koncepcję i wstępna analizę lekkiej kompozytowej struktury nośnej. Zastosowano w niej węzły kompozytowe łączące prefabrykowane pręty kompozytowe ze zbrojeniem szklanym i węglowym. Wykorzystanie takich gotowych prętów kompozytowych łączonych węzłami kompozytowymi pozwala na znaczące obniżenie masy struktury, skrócenie czasu jej wykonania i obniżenie ceny.
\end{abstract}

SŁOWA KLUCZOWE: struktury nośne, węzły kompozytowe

Paper discussed the idea and tests of the new composite space structure made of prefabricated load-bearing elements with glass and carbon as reinforcing material. Composite joints are applied as the proper solution for light space structures. Using of prefabricated load-bearing elements joined by composite joints allows to decrease mass of the structure, construction time and costs.

KEYWORDS: space structures, composite joints

Kompozytowe struktury nośne mają liczne zalety związane z małą masą oraz dużą wytrzymałością i sztywnością. Zbrojenie w postaci tkaniny bądź rovingu można układać tak, aby kompozytowy element konstrukcyjny w optymalny sposób przenosił obciążenie eksploatacyjne.

Technologie wytwarzania bazujące na mieszankach sycących chemoutwardzalnych są dość pracochłonne i wymagają bardzo doświadczonych pracowników. Wytwarzanie elementów z wykorzystaniem preimpregnatów zapewnia znacznie lepszą powtarzalność własności materiału, ale wymaga większych nakładów na infrastrukturę produkcyjną. Coraz częściej jako zbrojenie wykorzystuje się włókna pochodzenia naturalnego i w najbliższym czasie należy oczekiwać masowego zastosowania włókien bazaltowych, które staną się alternatywą dla włókien szklanych czy węglowych. Wydaje się to bardzo racjonalne rozwiązanie - nie tylko ze względu na koszt wytworzenia włókien bazaltowych, lecz także na ich własności wytrzymałościowe oraz odporność chemiczną (http://basalt.guru).

Bardzo istotnym aspektem wytwarzania materiałów kompozytowych są stosowane w nich syntetyczne żywice i utwardzacze - związki niezbyt przyjazne środowisku naturalnemu. Mieszanka sycąca jako mieszanina żywicy i utwardzacza po przesyceniu zbrojenia i zakończeniu procesu sieciowania transmituje obciążenie $z$ jednego włókna zbrojenia na drugie. Analogiczne związki pochodzenia naturalnego nie spełniają na razie wymagań wytrzymałościowych i dotyczących trwałości.

Konstruktor projektujący strukturę nośną bierze pod uwagę szereg wymagań związanych m.in. z zapewnieniem odpowiedniej nośności, trwałości, ceny i estetyki konstrukcji. W miarę możliwości wprowadza się nowe materiały i rozwiązania konstrukcyjne, które przechodzą

\footnotetext{
* Dr inż. Daniel Debski (daniel.debski@simr.pw.edu.pl) - Politechnika Warszawska, prof. dr hab. inż. Krzysztof Gołoś (krzysztof.golos@simr. pw.edu.pl) - Politechnika Warszawska, Instytut Mechanizacji Budownictwa i Górnictwa Skalnego
}

etapy od pomysłu, poprzez prace badawczo-rozwojowe, aż do wdrożenia.

W pracy przedstawiono koncepcję lekkiej konstrukcji nośnej z węzłami kompozytowymi. Nad tematyka węzłów kompozytowych autorzy pracują od wielu lat i stale ją rozwijają [1, 2]. Wykorzystanie w konstrukcji gotowych elementów kompozytowych w formie prętów ze zbrojeniem w postaci rovingu szklanego i węglowego jest nowym kierunkiem prac koncepcyjno-badawczych. Gotowe elementy kompozytowe mają kontrolowane i powtarzalne właściwości mechaniczne. Opracowana struktura nośna jest próbą optymalnego wykorzystania tych własności. Pierwowzorem dla tej struktury były plecione z wikliny kosze - konstrukcje bardzo lekkie i sztywne. Zastosowanie prętów kompozytowych pozwala na obniżenie masy konstrukcji nośnej oraz znaczące uproszczenie jej budowy. Problemem zawsze są i będą węzły konstrukcyjne.

\section{Węzły kompozytowe struktur nośnych}

Węzły struktury nośnej łączą poszczególne elementy struktury ze sobą, a także całe jej zespoły. Węzły to rejony konstrukcji, w których są wprowadzane i rozprowadzane siły skupione. Z reguły w obrębie węzłów struktury nośnej następuje inicjacja i rozwój uszkodzeń zmęczeniowych lub uszkodzeń doraźnych na skutek lokalnych spiętrzeń naprężeń i gwałtownych skoków sztywności. Typowe węzły konstrukcyjne wykonuje się w technologii spawanej, nitowanej lub klejonej, jak również w formie połączeń sworzniowych lub śrubowych. Każda z tych technologii ma swoje zalety i wady.

Alternatywnym sposobem łączenia elementów struktury nośnej są węzły kompozytowe [1], które według prekursora tej koncepcji połączeń - Krzysztofa Kotlińskiego - znalazły szerokie zastosowanie (rys. 1).

Dzięki wykorzystaniu koncepcji węzłów kompozytowych w strukturach nośnych można:

- łączyć elementy wykonane z różnych materiałów, trudnych do połączenia innymi metodami,

- tworzyć węzły o dużym stopniu skomplikowania (np. węzły łączące rury biegnące w wielu płaszczyznach),

- konstruować węzły zgodnie z optymalnym modelem ich pracy,

- uniknąć charakterystycznych dla konstrukcji spawanych odkształceń na skutek relaksacji wewnętrznych naprężeń powstałych podczas procesu spawania.

Węzły kompozytowe poddano próbom statycznym i zmęczeniowym. Badano wyizolowany węzeł łączący dwie współosiowe rury wykonane ze stopu aluminium (duralu) (rys. 2). Do badań wykorzystano trzy rodzaje węzłów, w których wzmocnienie stanowią odpowiednio włókna: szklane, kevlarowe i węglowe. Osnowę zbrojenia stanowiła żywica epoksydowa. Węzły wykonano przy założeniu jednakowego objętościowego współczynnika wzmocnienia, wynoszącego 0,5. 
TABLICA. Wyniki badań statycznych

\begin{tabular}{|c|c|c|c|c|}
\hline $\begin{array}{c}\text { Węzeł } \\
\text { (rodzaj zbrojenia) }\end{array}$ & $\begin{array}{c}\text { Obciążenie odpo- } \\
\text { wiadające liniowemu } \\
\text { zakresowi wydłużeń } \\
\text { próbki, kN }\end{array}$ & $\begin{array}{c}\text { Obciążenie } \\
\text { niszczące, kN }\end{array}$ & $\begin{array}{c}\text { Rodzaj uszkodzenia } \\
\text { Poziom naprężeń } \\
\text { przy uszkodzeniu } \\
\text { węzła, MPa }\end{array}$ & $\begin{array}{c}\text { Współczynnik bezpie- } \\
\text { czeństwa* }\end{array}$ \\
\hline szklany & 8,7 & 22 & pęknięcie kompozytu & 314 \\
\hline kevlarowy & 11 & 27 & pęknięcie kompozytu & 386 \\
\hline węglowy & 11 & 27,5 & uszkodzenie zaczepów & 393 \\
\hline * Współczynnik bezpieczeństwa jest rozumiany jako stosunek obciążenia niszczącego węzeł do obciążenia odpowiadającego liniowemu zakresowi wydłużeń próbki.
\end{tabular}
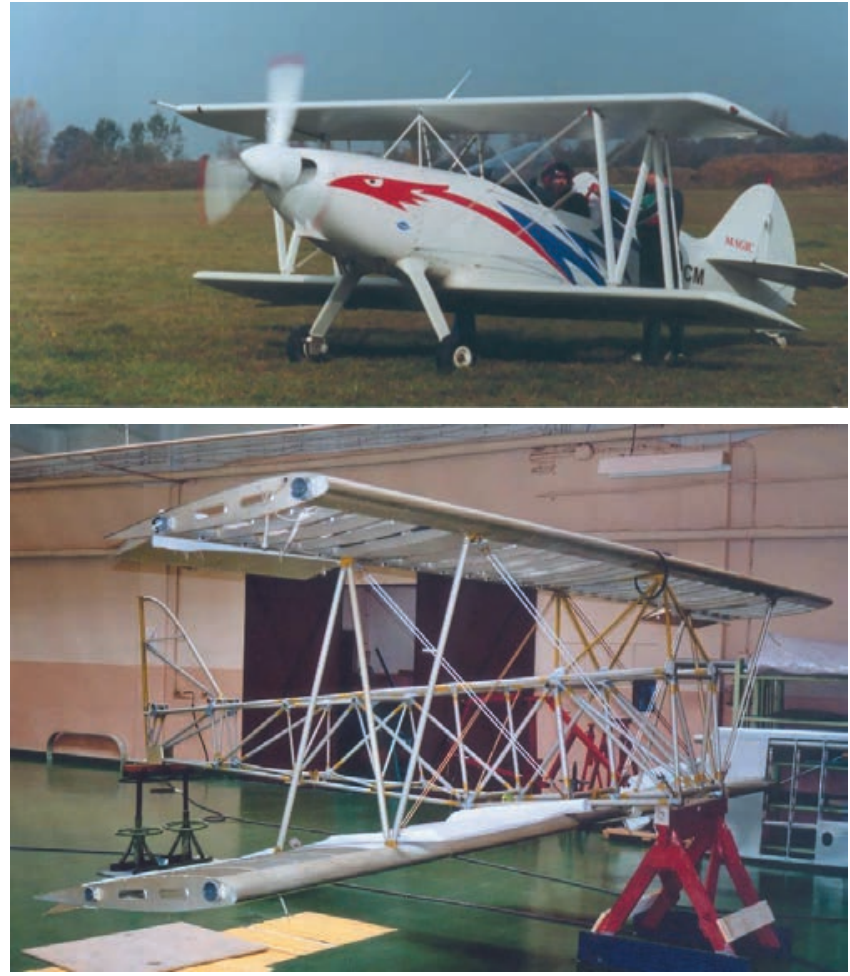

Rys. 1. Samolot DEKO 9 Magic - struktura nośna kadłuba została wykonana zgodnie z koncepcją węzłów kompozytowych (źródło: https://pl.wikipedia.org/wiki/DEKO-9_Magic)

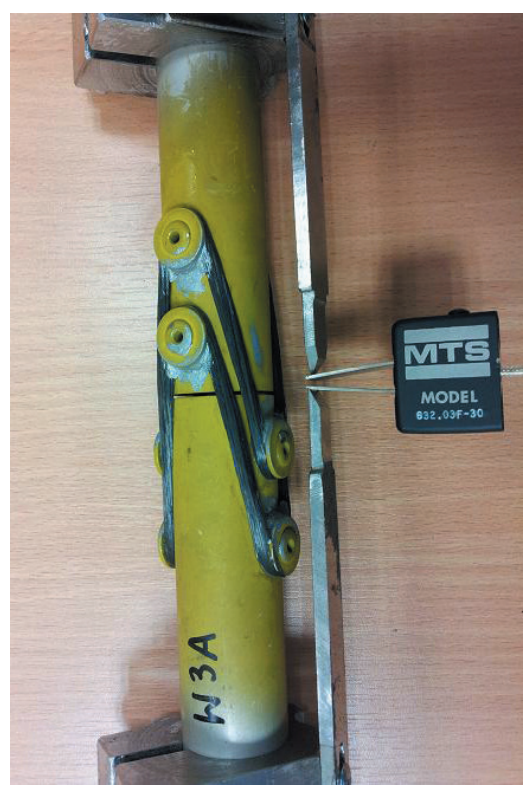

Rys. 2. Węzeł kompozytowy przygotowany do badań

$\mathrm{Na}$ rys. 3 przedstawiono przebiegi siły rozciągającej próbkę w funkcji jej wydłużenia. W tablicy zestawiono wyniki badań wytrzymałości statycznej. Proces niszczenia węzła kompozytowego nie ma charakteru gwałtownego
- jest sygnalizowany dużymi odkształceniami połączenia przy jednoczesnym zachowaniu zdolności węzła do przenoszenia narastającego obciążenia. Węzły kompozytowe dają możliwość uzyskania najlepszego stosunku wytrzymałości połączenia (statycznej i zmęczeniowej) do jego masy.

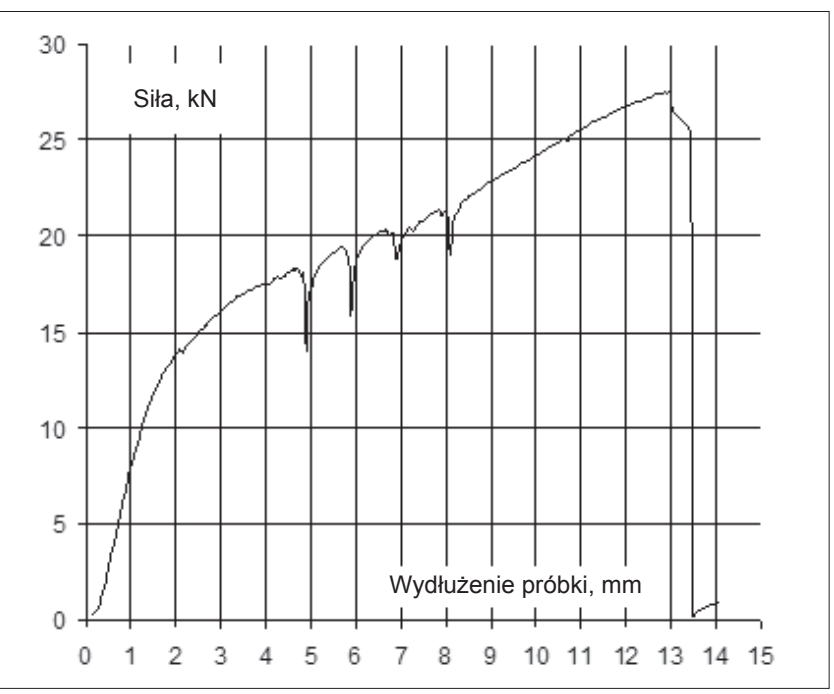

Rys. 3. Próba rozciągania - węzeł ze zbrojeniem węglowym

W trakcie badań zmęczeniowych węzłów co określoną liczbę cykli rejestrowano kilka cykli tworzących pętle histerezy w relacji: siła poosiowa - wydłużenie próbki. Zaobserwowano pętle histerezy świadczące o zdolności tego typu połączeń do rozpraszania energii, a więc tłumienia (rys. 4). Jest to bardzo pozytywna cecha w przypadku ustrojów nośnych narażonych na drgania [3].

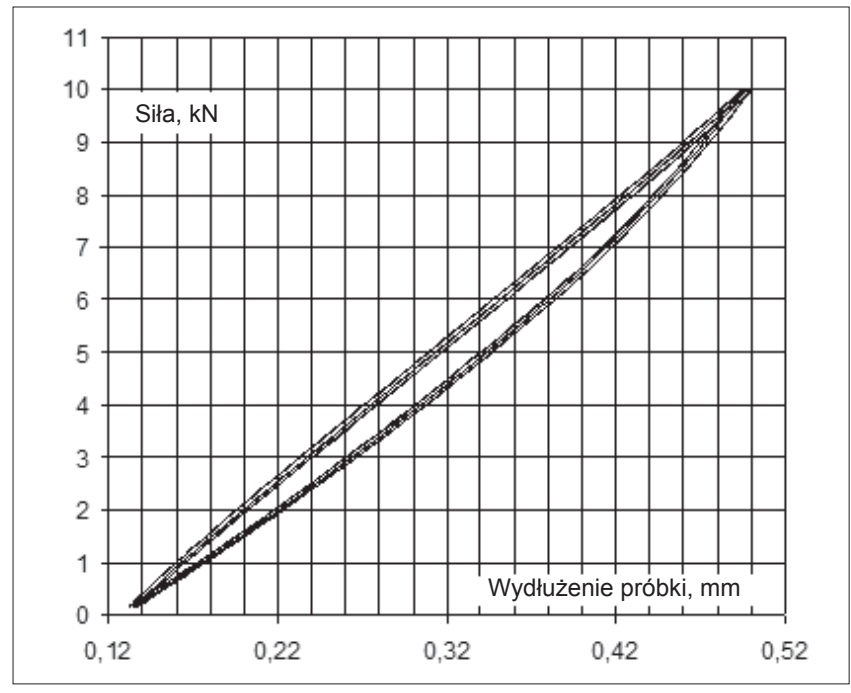

Rys. 4. Węzeł ze zbrojeniem węglowym - kilka cykli tworzących pętle histerezy w relacji siła poosiowa - wydłużenie próbki 
Autorzy zdecydowali o zastosowaniu węzłów kompozytowych w koncepcji lekkiej kompozytowej struktury nośnej ze względu na omówione wcześniej właściwości oraz możliwość ich aplikacji bez posiadania zaawansowanego wyposażenia. Wykorzystane węzły nie do końca spełniły jednak wymagania dotyczące powtarzalności budowy i własności połączenia. Obecnie trwają prace nad rozwijaniem węzłów kompozytowych o zdecydowanie prostszej budowie.

\section{Wstępne badania struktury nośnej z węzłami kompozytowymi}

Koncepcja lekkiej konstrukcji nośnej z węzłami kompozytowymi bazuje na wykorzystaniu gotowych prętów kompozytowych ze zbrojeniem w postaci rovingu szklanego i węglowego (rys. 5 i 6). Zaletą prefabrykowanych prętów kompozytowych są kontrolowane i powtarzalne właściwości mechaniczne. Dzięki użyciu takich prętów łączonych węzłami kompozytowymi znacznie upraszcza się technologia budowy oraz obniża masa konstrukcji. W pracy [4] przeprowadzono szereg wstępnych analiz numerycznych, w których lekką strukturę nośną poddawano ściskaniu, zginaniu i skręcaniu.

Szkielet struktury nośnej składał się z pięciu wręg, ośmiu węglowych prętów równoległych do osi konstrukcji oraz prętów ze zbrojeniem szklanym, oplatających konstrukcję. Naprężenia zredukowane w strukturze poddanej odpowiednio ściskaniu i zginaniu pokazano na rys. 7.

\section{Perspektywy rozwoju lekkich kompozytowych struktur nośnych}

Optymalne wykorzystanie właściwości kompozytowych materiałów konstrukcyjnych i metod ich łączenia będzie przez najbliższe lata podstawą wielu prac inżynierskich i badawczych. Rozwój zaproponowanej koncepcji lekkiej struktury nośnej jest mocno uzależniony od dopracowania samych węzłów łączących gotowe elementy konstrukcyjne (pręty bądź rury kompozytowe). Dzięki takim elementom połączonym węzłami kompozytowymi możliwe byłoby urzeczywistnienie wizji samolotu przedstawionego na rys. 8 - konstrukcji bardzo lekkiej, a zarazem wytrzymałej.
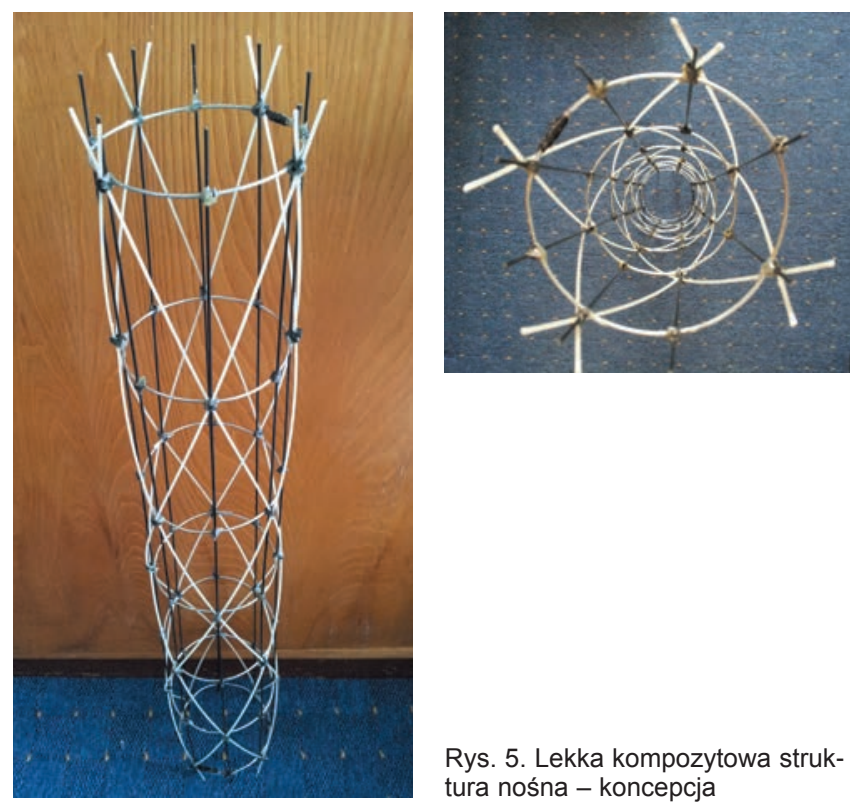

Rys. 5. Lekka kompozytowa struktura nośna - koncepcja

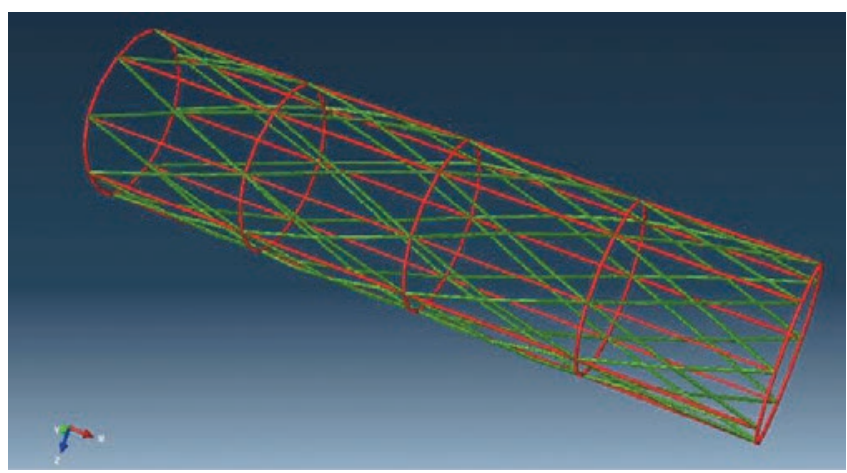

Rys. 6. Geometria konstrukcji z prętami ze zbrojeniem węglowym (oznaczonymi kolorem czerwonym) i szklanym (oznaczonymi kolorem zielonym)

a)

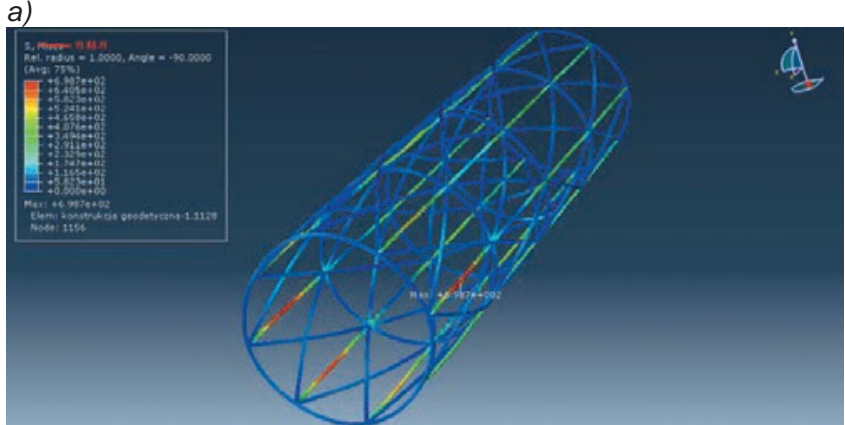

b)

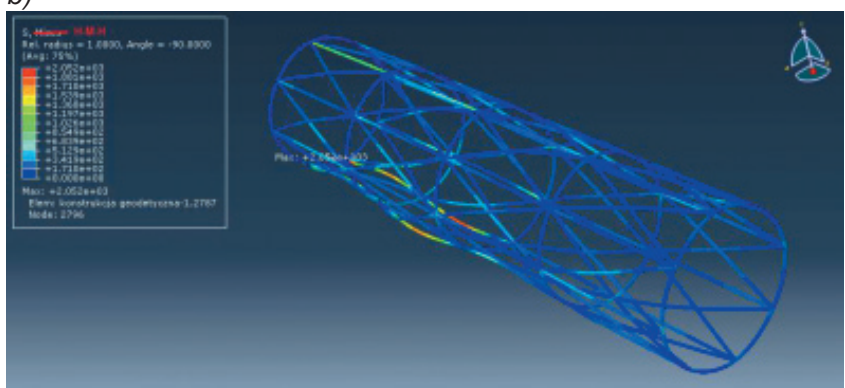

Rys. 7. Naprężenia zredukowane (według hipotezy Hubera-Misesa-Hencky'ego): a) podczas ściskania, b) podczas zginania

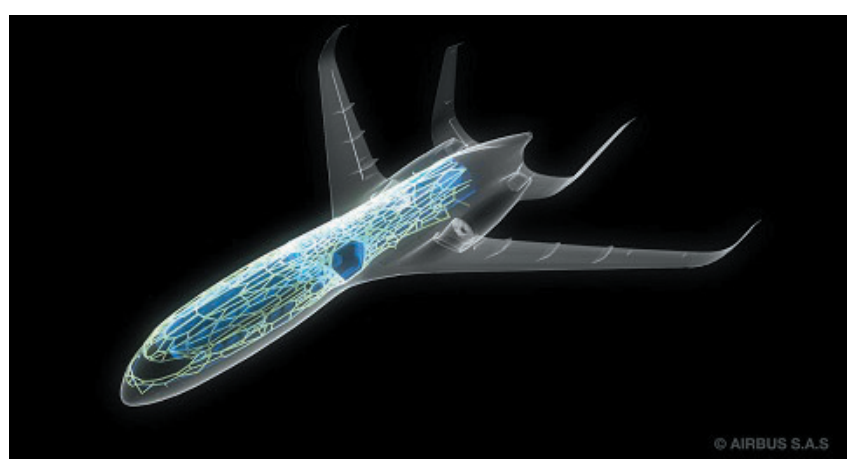

Rys. 8. Wizja samolotu o konstrukcji kadłuba podobnej do proponowane struktury nośnej (źródło: Airbus)

\section{LITERATURA}

1. Dębski M., Gołoś K., Dębski D. "Composite Joints of Aerostructures". Transactions of the Institute of Aviation. Iss. 170-172 (2002): pp. 3-27.

2. Dębski M., Dębski D. „Wybrane zagadnienia wytrzymałości zmęczeniowej konstrukcji lotniczych". Biblioteka Naukowa Instytutu Lotnictwa. 36 (2014).

3. „Redukcja drgań w układach wirujących i ustrojach nośnych poprzez monitorowanie właściwości sprężysto-tłumiących za pomocą materiatów , inteligentnych" $i$ „kompozytowych". Monografia pod red. Z. Starczewskiego. Warszawa: Politechnika Warszawska, 2014.

4. Michalski K. „Prototypowa konstrukcja geodetyczna wykonana z prętów kompozytowych". Praca magisterska. Politechnika Warszawska, 2014. 